\title{
„Die hellsten Köpfe für die Radiologie“ - Anmeldung bis 28. Februar möglich!
}

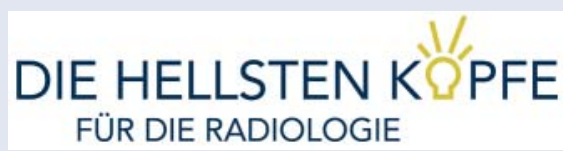

Nachwuchsprogramm zum 98. Deutschen Röntgenkongress und 8. Gemeinsamen Kongress der DRG und ÖRG/ 24.-27. Mai 2017 in Leipzig

Noch bis zum 28. Februar 2017 können Sie Ihre „hellsten Köpfe“ für das Nachwuchsprogramm des Deutschen Röntgenkongresses anmelden.

Wie die Anmeldung für das Stipendium funktioniert, erfahren Sie im Internet auf www.hellste-koepfe.de.

Das erwartet die „hellsten Köpfe“ in Leipzig

- DB-Kongressticket: Hin- und Rückfahrt

2. Klasse für Leipzig
- Drei Übernachtungen in einem Innenstadt-Hostel vom 24.-27. Mai 2017 (Übernachtungen im Mehrbettzimmer inkl. Frühstück)

- Kostenloser Zugang zu den Veranstaltungen des 98. Deutschen Röntgenkongresses/8. Gemeinsamen Kongresses der DRG und ÖRG
- Einladung zum Kongress-Sonderprogramm „Radiologie für Studenten“

- Einladung zum Kongress-Eröffnungsabend am Mittwoch, 24. Mai 2017

- Studentenlounge mit freiem WLANZugang und täglicher Kongressberatung sowie Snacks und Getränken

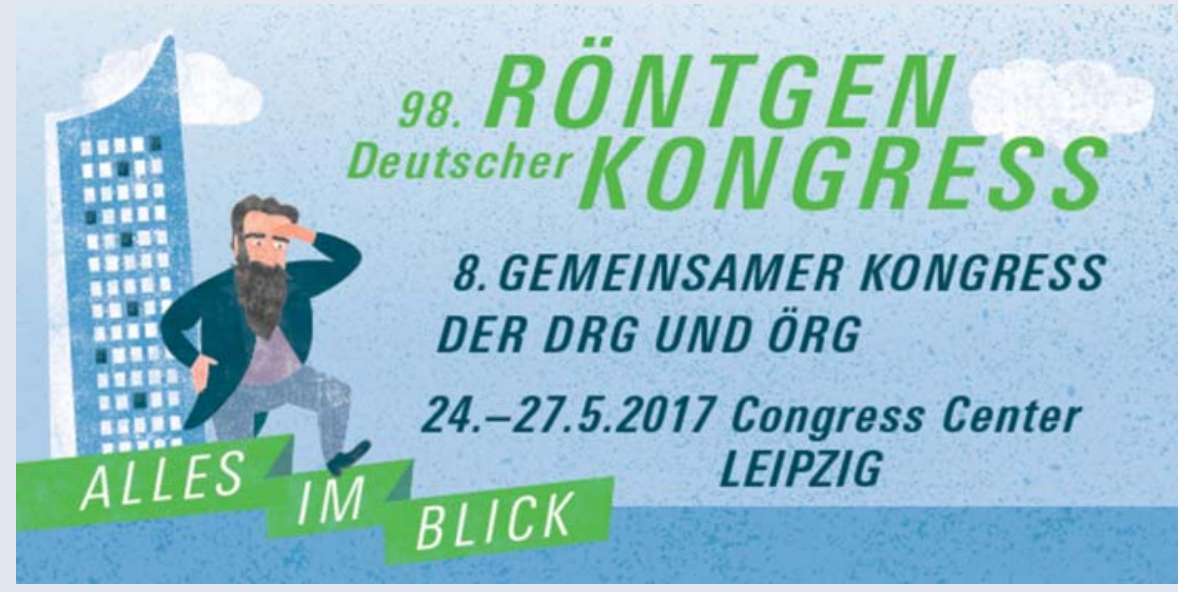

